\title{
HUMAN VALUES AND SOCIAL ASSISTANCE: A STUDY OF MUNICIPAL COUNCIL REPRESENTATIVES
}

\section{CLEUSIMAR CARDOSO ALVES ALMEIDA}

Master's Degree in Public Management and Society from the Department of Public

Management and Society,

Federal University of Alfenas (Unifal).

Professor at the Department of Social Sciences,

Universidade Vale do Rio Verde.

Avenida Castelo Branco, 82, Chácara das Rosas, Três Corações - MG - Brasil - CEP 37410-000

E-mail: cleocardoso08@gmail.com

\section{VIRGÍNIA DONIZETE CARVALHO}

$\mathrm{PhD}$ in Social Psychology from the Department of Social Psychology,

Federal University of Rio Grande do Norte (UFRN).

Professor at the Department of Public Management and Society,

Federal University of Alfenas (Unifal).

Rua Celina Ferreira Ottoni, 4000, Padre Vitor, Varginha - MG - Brasil - CEP 37048-395

E-mail: virginiadcarvalho@gmail.com 


\section{ABSTRACT}

Purpose: Analyze the motivational types of human values prioritized by representatives of Municipal Social Assistance Councils in the municipalities of State of Minas Gerais, in an attempt to establish the axiological profiles of study participants.

Originality/gap/relevance/implications: The study is based on Schwartz's (1992) theory of human values, applying its contributions to understand a reality yet unexplored in research of values, namely the Social Assistance Councils in Brazil, notwithstanding the recent transformations aimed at changing their conception as public policy.

Key methodological aspects: Data were collected applying the PQ-21 questionnaire to a sample of 204 respondents. Descriptive analyses, the Anova test and cluster analyses were used.

Summary of key results: The motivational types most emphasized by the respondents were Benevolence and Universalism, followed by Self-direction, Tradition and Security, revealing the recognition of interests of social groups and the community, in addition to the need to affirm one's own ideas and preserve traditional and safe practices. Five axiological profiles were identified from cluster analyses, and in four out of these, Self-transcendence was the key characteristic.

Key considerations/conclusions: The relevance attributed to Self-transcendence and Conservation, in that order, indicates a certain concern with social well-being and political participation, though with a tendency to accept and maintain traditional practices, which may hinder the transformation processes in the context under study. Future studies may clarify these relations, benefitting from the complementary use of a qualitative survey.

\section{KEYWORDS}

Human values. Social assistance. Municipal councils. Municipal council representatives. Social participation. 


\section{INTRODUCTION}

Social Assistance Councils in Brazil are regulated systemic management instruments that execute Social Assistance Public Policy to promote democratization and have decision-making power in all areas of government. Conceived as public forums to determine the demands and specific interests of different social groups, they are a pathway to expand participation through segments of society with little access to the state apparatus (Raichelis, 2007).

It is important to underscore the vital role of Municipal Social Assistance Councils (MSAC), which are regulated in $99.3 \%$ of Brazilian municipalities (Instituto Brasileiro de Geografia e Estatística, 2010). For example, in the State of Minas Gerais, all 833 municipalities have an MSAC (Brasil, 2013). Their current potential, however, is offset by a number of barriers, including, fragmented participation, indirect selection of representatives, predominance of the political clientele culture, lack of qualification to perform the duties of counselor and shortage of communication channels between the population and the council (Dagnino, 2002; Oliveira, 2009; Falchetti, 2011; Kronemberger, Tenório, Dias, \& Barros, 2012; Alves, Damião, \& Mafra, 2013).

Despite the constraints on the operation and performance in these councils, their representatives play a pivotal role and can contribute to transform the current situation. Decision-making processes in councils are influenced by different variables and among them are the counselors' values. Understanding them may contribute to determining the profile of these social actors, since values guide their behavior (Tamayo \& Schwartz, 1993; Schwartz, 1994; Jesuíno, Torres, \& Teixeira, 2012; Torres, Porto, Vargas, \& Fischer, 2015) and, as such, influence the position adopted in the MSAC deliberative processes.

The growing number of researchers interested in studying values and the broadening topics in this field have been reported by Jesuíno et al. (2012). Initiatives carried out in the last 20 years include Schwartz's (1992) theory of personal values, which describes a set of individual needs that identify motivational types of universal values. With a consolidated and tested background in several empirical studies, the theory has been used to understand and predict individual differences and explain the decision making process involving different realities (Porto \& Tamayo, 2002; Leite, Tamayo, \& Günther, 2003; Coelho, Gouveia, \& Milfont, 2006; Sobral \& Gimba, 2012, Porto \& Torres, 2014; Torres et al., 2015; González-Rodrigues, Díaz-Fernández, 
Spers, \& Leite, 2016, among others), although no studies have used it to investigate Social Assistance Councils and their policies.

As such, this study aimed to analyze the motivational types of human values emphasized by the representatives of municipal Social Assistance Councils in the State of Minas Gerais, in order to describe the axiological profiles of participants. Only MSAC representatives were included because they tend to better understand the forces at play in the councils, as well as the policies and attributions (Raichelis, 2007), making these actors the central focus of this scenario. This article initially discusses the context of Social Assistance Councils and counselors in Brazil and presents the model adopted to study their human values. Next, the research methodology is described, the results are analyzed and discussed, concluding with some observations regarding the main findings and their implications, as well as listing the contributions and limitations of the study.

\section{SOCIAL ASSISTANCE COUNCILS IN BRAZIL}

As defined in the Organic Social Assistance Law (Loas, Law no. 8.742/1993), Social Assistance policy is determined by Federal, State, Federal District and Municipal governments, and initiatives in this area are managed based on instruments that regulate and standardize procedures, strategies and the participative process (Brasil, 2011), particularly Social Assistance Councils, whose role is to debate social protection policies according to the population needs, in addition to deliberate, control, regulate, monitor and assess these needs (Raichelis, 2007).

Operating in all spheres of government, $50 \%$ of council members are elected from civil society, and 50\% are appointed by the executive branch. Civil society counselors are users of social assistance and/or from user organizing entities, professionals from the area and social assistance non-governmental organizations. The public sector representatives belong to institutions linked to the municipal government, such as social assistance departments.

Counselors are public agents with decision-making authority in matters of public interest, providing an important, non-remunerated public service. As public agents, they must observe the principles of public administration and infra-constitutional supremacy of the public interest. Their responsibilities include deliberating proposals and resolutions, public expenditures, as well as inspecting and monitoring services, programs, projects and public social assistance benefits, and their decisions are published in the Official 
Federal Gazette and/or major newspapers. Their contribution has led to advances in services, programs, projects and benefits of the area, in spite of some shortcomings still present in MSAC.

At the municipal level, these agents, whether representatives of public entities or civil society, advise, deliberate, control and manage federal and state funds targeting social assistance, in addition to overseeing social expenditures and the performance of approved projects and programs. They also deliberate the registration criteria of organizations and assess their activities, as well as mobilize civil society through meetings, conferences, and forums to discuss services, programs and projects in the area and the social assistance requirements of the municipality (Conselho Nacional de Assistência Social, 2011).

Given that the relatively recent transformations in Brazilian social assistance represent a change in its concept of public policy, the process of rethinking established values is still ongoing, but demands the cooperation of those involved in order to be effectively applied in practice. In this respect, it is important to reflect on the role of counselors, whose perceptions and attitudes are governed by their personal values, which, as discussed below, tend to influence their behavior and therefore deserve the attention of councils.

\section{SCHWARTZ'S THEORY OF PERSONAL VALUES}

The issue of values has received the attention of researchers from several disciplines such as Cultural Anthropology, Political Economics, Sociology and Social Psychology, giving rise to a number of theoretical models (Ros, 2006). Scholars consider human values a key element of culture (Schwartz, 1994; 2005; Ros, 2006); they contribute to understand behaviors, attitudes, choices and lifestyles, since they guide and explain actions, influencing, for example, decision making and judgment (Tamayo \& Schwartz, 1993; Schwartz, 1994; 2005; Jesuíno et al., 2012; Torres et al., 2015).

One definition of the primary characteristics of values, widely reproduced in the literature, was initially put forward by Schwartz and Bilsky (1987) and later by Schwartz (1992; 1994; 2005), in which values are: (1) beliefs linked to emotion that, once activated, evoke positive or negative feelings; (2) desirable objectives that spur one to perform an action considered adequate; (3) transcendent to specific situations and actions, considering their abstract nature; (4) guides to select and assess behaviors, actions, policies, people or events, and serve as standards or criteria for actions and decisions; 
and (5) arranged according to their relative importance, forming a system of priorities for each individual.

These same authors (Schwartz \& Bilsky, 1987; Schwartz, 1992; 1994; 2005) assume that the motivational types of values tend to be universal, since they are based on a number of requirements considered basic to human existence, such as the needs of individuals as biological organisms; the need for coordinated social interaction and the social demands of group survival and well-being. As such, to construct the theory of personal values based on these requirements, Schwartz (1992) developed a framework of ten motivational types, which are listed in Chart 1 with their respective definitions and core values.

\section{(Chart 1) \\ MOTIVATIONAL TYPES OF VALUES}

\begin{tabular}{|c|c|c|}
\hline $\begin{array}{l}\text { Motivational } \\
\text { type }\end{array}$ & Definition & Values \\
\hline Power & $\begin{array}{l}\text { Social status and prestige, control or } \\
\text { dominance over people and resources, } \\
\text { preservation of public image. }\end{array}$ & Social power, authority, riches, vanity. \\
\hline Achievement & $\begin{array}{l}\text { Personal success through demonstrating } \\
\text { competence according to social } \\
\text { standards. }\end{array}$ & $\begin{array}{l}\text { Success, successful, capable, } \\
\text { ambitious, influential. }\end{array}$ \\
\hline Hedonism & $\begin{array}{l}\text { Pleasure or sensuous gratification for } \\
\text { oneself. }\end{array}$ & Pleasure, enjoying life, self-indulgent. \\
\hline Stimulation & Excitement, novelty, and challenge in life. & A varied life, an exciting life, daring. \\
\hline Self-Direction & $\begin{array}{l}\text { Independent thought and action- } \\
\text { choosing, creation, exploitation. }\end{array}$ & $\begin{array}{l}\text { Creativity, freedom, choosing own } \\
\text { goals, curious, independent, self- } \\
\text { respect, intelligent, privacy. }\end{array}$ \\
\hline Universalism & $\begin{array}{l}\text { Understanding, appreciation, tolerance, } \\
\text { and protection for the welfare of all } \\
\text { people and for nature. }\end{array}$ & $\begin{array}{l}\text { Broadminded, social justice, equality, } \\
\text { world at peace, world of beauty, unity } \\
\text { with nature, wisdom, protecting the } \\
\text { environment, inner harmony, a spiritual } \\
\text { life. }\end{array}$ \\
\hline Benevolence & $\begin{array}{l}\text { Preserving and enhancing the welfare } \\
\text { of those with whom one is in frequent } \\
\text { personal contact (the 'in-group') }\end{array}$ & $\begin{array}{l}\text { Helpful, honest, forgiving, responsible, } \\
\text { loyal, true friendship, mature love, } \\
\text { sense of belonging, meaning in life, a } \\
\text { spiritual life. }\end{array}$ \\
\hline
\end{tabular}

(continue) 


\section{(Chart 1 (conclusion)) \\ MOTIVATIONAL TYPES OF VALUES}

\begin{tabular}{|c|c|c|}
\hline $\begin{array}{l}\text { Motivational } \\
\text { type }\end{array}$ & Definition & Values \\
\hline Tradition & $\begin{array}{l}\text { Respect, commitment, and acceptance of } \\
\text { the customs and ideas that one's culture } \\
\text { or religion provides. }\end{array}$ & $\begin{array}{l}\text { Respect for tradition, humble, devout, } \\
\text { accepting my portion in life, moderate, } \\
\text { spiritual life. }\end{array}$ \\
\hline Conformity & $\begin{array}{l}\text { Restraint of actions, inclinations, and } \\
\text { impulses likely to upset or harm others } \\
\text { and violate social expectations or norms. }\end{array}$ & $\begin{array}{l}\text { Obedient, self-discipline, politeness, } \\
\text { honoring parents and elders, loyal, } \\
\text { responsible. }\end{array}$ \\
\hline Security & $\begin{array}{l}\text { Safety, harmony, and stability of society, } \\
\text { of relationships, and of self. }\end{array}$ & $\begin{array}{l}\text { Social order, family security, national } \\
\text { security, clean, reciprocation of favors, } \\
\text { healthy, moderate, sense of belonging. }\end{array}$ \\
\hline
\end{tabular}

Source: Adapted from Leite et al. (2003) and Schwartz (2005).

Relations between the ten motivational types of values identified by Schwartz (1992) involve conflict (opposition) or compatibility and are grouped into two bipolar dimensions, in a circular structure. These dimensions are denominated Openness to Change versus Conservation and Self-transcendence versus Self-promotion.

The Self-transcendence domain refers to concern for the well-being of others and contains the motivational types Benevolence and Universalism. By contrast, Self-promotion proposes dominance over others and arranges values based on the personal motivation to promote one's own interests and success at the expense of others, comprising Achievement, Power and Hedonism (Schwartz, 1992; 1994; 2005). Hedonism can be classified in the Self-promotion or Openness to Change dimension. The latter involves values that predispose to change, according to the goals of individuals in promoting their own interests, and includes Self-direction and Stimulation. The Conservation dimension concerns the preservation of traditional practices, the tendency to preserve what is safe and traditional, and contains the motivational types Tradition, Conformity and Security (Schwartz, 1992; 1994; 2005).

According to Porto and Torres (2014), of the value structures that have been empirically validated in different cultures, Schwartz's (1992) is the most widely used in studies focusing on the individual level. Initially tested in 20 countries (Schwartz, 1992) and later incorporating new samples, it was assessed in 44 countries (Schwartz, 1994), a number that continued to grow, allowing the theory to evaluate individuals from 67 countries (Sch- 
wartz, 2005) on all the continents. In Brazil, this structure was tested when Tamayo and Schwartz (1993) applied the instrument developed by Schwartz (1992), obtaining evidence of its applicability in the Brazilian setting.

As reported by Teixeira, Sambiase, Janik and Bilsky (2014, p. 140), the theory of personal values "has been amended over the years". More recently, Schwartz et al. (2012) updated the value structure, resulting in a new proposal involving 19 motivational types, derived from the initial model. The study reaffirms the central assumption that the values form a circular motivational continuum, structured by the same two bipolar dimensions with their relations of conflict and compatibility. According to the authors, the proposal of refining the theory aimed at providing greater explanatory power compared to the original structure of ten motivational types.

Teixeira et al. (2014) underscore, however, that the new proposal is not as sound as the original, since it was tested in fewer countries. As such, the authors used the original structure of ten motivational types to analyze the empirical structure of Brazilian values, based on a representative sample. They observed that, among Brazilians "the values of Benevolence were located in the inner part of the circle and Universalism in the outer part; Hedonism and Stimulation were found in a single region; and Conformity was adjacent to the values of Tradition and Security" (Teixeira et al., 2014, p. 139).

Using Schwartz's theory (1992), several studies have correlated personal values to different aspects of human behavior, such as intergroup contact, cooperation, political orientation, pro-environmental behavior, the use of legal recourses and conflict resolution. Other studies have investigated the relations between value priorities and social policies and between individual experiences and personal values related to well-being (Schwartz, 2011). In this study, the theory of personal values will be applied in the context of Social Assistance policies, in order to analyze the motivational types of human values prioritized by MSAC representatives in the municipalities of State of Minas Gerais.

\section{METHODOLOGICAL PROCEDURES}

The study population consisted of 853 Municipal Social Assistance Council representatives of Minas Gerais, from which a probability sample of 204 respondents was selected from all regions of the state. Most of the participants were women $(67.6 \%)$, with an average age of 39 years $(\mathrm{SD}=11.25)$, and holders of a graduate degree $(39.7 \%)$, undergraduate degree $(30.4 \%)$, and family income between 1 and $3(46.1 \%)$ and 4 and $5(32.8 \%)$ minimum 
monthly wages. In relation to the situation in the council, most were full members (69.6\%) and public authorities representatives $(52.7 \%)$. Although average time as MSAC representatives was 31 months $(\mathrm{SD}=31.24)$, some (15.8\%) reported being in the function for more than five years, and others up to 15 years. The latter group, however, had belonged to councils before approval of the United Social Assistance System (Suas) and the revision of the Loas, approximately five years ago.

The data were collected using the PVQ-21 (Portrait Values Questionnaire) and a sociodemographic chart. The PVQ-21 was translated, adapted and tested in Brazil by Sambiase et al. (2014), and the theoretical framework of its basic values was confirmed. It is composed of 21 questions representative of Schwartz's (1992) ten motivational types of values, which describe the objectives, aspirations or desires that illustrate the importance of a motivational type of value in a person (Schwartz, 1994).

Data collection occurred in two stages. In the first stage, at a Social Assistance Conference attended by council representatives from different regions of Minas Gerais, different civil society organizations (users, workers and social assistance entities) and the public sector, providing the research with accessibility (for being at the same location) and quick responses. After the respondents were identified by their registration number, 260 questionnaires were handed out, 160 of which were completed. At a second stage, questionnaires were distributed by email to 213 respondents, 44 of which were filled out, representing a response rate of $43.1 \%$.

Data analysis involved calculating the mean, standard deviation, frequencies, Anova test of repeated measures and cluster analysis, in order to delineate the respondents' profile, identify the personal values of MSAC representatives in Minas Gerais and describe the axiological profiles of the study participants.

\section{RESULTS}

To analyze the motivational types of human values that were priority for Municipal Social Assistance Council representatives in the municipalities of Minas Gerais, the means attributed by the respondent to each motivational type of value were calculated. Next, the Anova test of repeated measures was applied to analyze the differences between the means attributed to the ten motivational types of values under study $(\mathrm{F}=123.28, \mathrm{p}<0.001)$. The results presented in Table 1 indicate that the most important values for the Council representatives are Benevolence and Universalism, whose measures 
show no statistically significant difference; the same occurred with Self-direction, Tradition and Security, which tied for second place. Conformity, Hedonism and Achievement placed third in this hierarchy, with Stimulation and Power occupying the last positions.

\section{(Table 1) \\ HIERARCHY OF THE MOTIVATIONAL TYPES OF VALUES OF MSAC REPRESENTATIVES FROM MINAS GERAIS}

\begin{tabular}{ccc}
\hline Motivational Types of Values & Mean & Standard Deviation \\
\hline Benevolence & 5.36 & 0.81 \\
\hline Universalism & 5.30 & 0.73 \\
\hline Self-direction & 4.83 & 0.98 \\
\hline Tradition & 4.56 & 1.01 \\
\hline Security & 4.56 & 1.03 \\
\hline Conformity & 4.11 & 1.09 \\
\hline Hedonism & 4.07 & 1.19 \\
\hline Achievement & 3.87 & 1.31 \\
\hline Stimulation & 3.78 & 1.08 \\
\hline Power & 2.98 & 1.07 \\
\hline
\end{tabular}

Source: Elaborated by the authors.

The means attributed to Benevolence $(M=5.36)$ and Universalism $(\mathrm{M}=5.30)$ show a motivational emphasis shared by adjacent types, as reported by Schwartz (2005), which involves putting concern for others ahead of personal interests. Taken together, these motivational types also make up the value Self-transcendence, which emphasizes the acceptance of equality among people and interest in their well-being, and contrasts with Self-promotion (Achievement and Power), prioritizing personal success and domination over others, forming one of the dimensions of the model. This conflict is clearly evident in the findings of this study, given that, in contrast to Self-transcendence, which was a priority, Self-promotion was among the least emphasized by the subjects. Indeed, this corresponds to the profile expected from MSAC representatives, given their concern with guaranteeing equal social and political rights to people and families in situations of vulnerability and social risk. 
Studies show a tendency for Benevolence and Universalism scores to be higher than the other motivational types, as observed in the meta-analysis conducted by Torres et al. (2015), who tested the variation of human values in Brazil, measured according to Schwartz's (1992) proposal. Nevertheless, it is important to remember that, in addition to this aspect, the differences in ascribing values to the remaining motivational types must be considered, since this is what will make up the entire set of axiological priorities of each group in question. With respect to this tendency, the aforementioned authors report that, despite the importance attributed to Benevolence and Universalism throughout Brazil, systematic differences in value hierarchy were observed in those surveyed in the five regions of the country. As such, the greatest relevance attributed to Benevolence and Universalism in this study must be understood in conjunction with the position of other motivational types in this hierarchy.

In relation to equality between the measures of Benevolence and Universalism observed here, Teixeira et al. (2014) analyzed the empirical structure of Brazilian values, obtaining results that corroborated earlier investigations in the country (Tamayo \& Porto, 2009; Sambiase et al., 2014), whereby these values were located in the same region or in the internal and external areas of a same region of the circular structure, respectively. They report that this is a sign of a more abstract position of Universalism in relation to Benevolence, which may be partially explained by some aspects of national culture (Teixeira et al., 2014), such that the values that make up Universalism are not achieved by concrete daily actions in Brazil.

Applying these observations to the case in question, it seems that the values of Benevolence would have greater weight in guiding the actions of MSAC representatives in Minas Gerais. According to Schwartz (2005), those who prioritize Benevolence aim to preserve and strengthen solidarity among the groups they belong to and concern for the well-being of individuals they come in contact with is more common in day-to-day relations. As such, this may be an indication that counselors tend to be more concerned with the sector and/or institution they represent than the broader collective interest. For example, MSACs may have representatives of CRAS, Creas, Apae (Reference Center for Social Assistance, Specialized Reference Center for Social Assistance, Association of Parents and Friends of the Disabled People) and NGOs, which, in turn, seek to meet the demands and interests of these segments, due to the close relations they have with individuals from these sectors.

The current concept of Universalism, however, is that everyone in the world should be treated equally, and have equal opportunities in life (Sch- 
wartz, 1994), emphasizing equality, social justice and knowledge. Thus, the universalization of social rights, which, to a certain extent, would contribute to the democratic potential of the Councils in debates and negotiations regarding management decisions and the establishment of proposals and guidelines, recognizing the dialogue between users, workers in the field, public institutions and NGOs, may not be occurring in practice, given the tendency to the abstract position of Universalism in the empirical structure of Brazilian values (Teixeira et al., 2014).

This has been reported by a number of authors (Oliveira, 2009; Falchetti, 2011; Kronemberger et al., 2012; Alves et al., 2013), who studied the reality of MSAC actions and observed difficulties such as the tendency to fragmentary defense of interests (defending the interests of the ruling group, the NGO in which they work or volunteer, among others); lack of dissemination and information in the community regarding the councils; predominance of political clientele; nonexistence of communication channels between the population and the council; a certain disparity between the representatives of different segments; lack of social coordination and a gap between representatives and the represented, among others.

Thus, all of these data suggest that, although the Council representatives consider democracy and social equality to be important values, their abstract position may not favor more participatory attitudes, respect for the space and opinions of all those involved, and effective commitment to socially vulnerable populations and the social assistance policy of guaranteeing rights and promoting human development.

Furthermore, according to Schwartz's (2005) theory, motivations behind the values of Universalism are interrelated with those of Self-direction, which is second in the hierarchy of values of the subjects surveyed $(M=4.83)$ (along with the values of Tradition and Security), emphasizing confidence in one's own judgment and acceptance of the diversity of existence. The values of Self-direction were more marked in individuals who like to make their own decisions and do not depend on others (Schwartz, 2005). Following these concepts, Council representatives guided by values of Self-direction tend to make their own decisions to the detriment of the collective position. The negative aspect of this attitude lies in the potential centralization of dialogue in discussions. This could result in the primacy of one sector, for example, the public sector, in terms of conducting meetings, as well as failure to accept the opinion of other representatives, imposing their ideas and defending their positions. As such, the sharing of deliberations would become slightly more restrictive, possibly transforming into a function of consultancy (Kronemberger et al., 2012). 
The positive aspect, however, is that the independent thought implicit in non-subordination to other individuals would lead Council representatives to give their own opinions on their positions and deliberations in the MSAC. On the other hand, it was observed that Self-direction values in this study tend to be linked more to the sense of affirmation of the representatives' own ideas rather than the collective position. This reinforces the emphasis on personal interests, since application of the t-test to determine which Self-direction-related values were most prioritized indicated that the item pertaining to making one's own decisions, being free and not depending on others obtained the highest mean $(t=3.91 ; p=0.00)$, especially for public authorities representatives $(M=5.00 ; S D=1.23)$ compared to representatives of civil society $(M=4.21 ; S D=1.63)$.

Tradition ranked second in the hierarchy of values $(M=4.56)$, with the basic social function of encouraging the behavior of group members, preserving old customs, and accepting the ideas and culture of the society to which one belongs (Schwartz, 2005). This may contribute to the Councils' maintaining old autocratic and corporate practices inherited from the sociopolitical scenario in Brazil. This could occur, for example, by preserving long-standing representatives (the data of this study demonstrate the presence of council representatives who have been serving for around 15 years), who can be nominated by allies or by belonging to the municipal government, leading to low turnover of new members. Moreover, the lack of communication channels between the population and the Council and the priority of placing public authorities or privileged groups in strategic positions, such as the presidency or vice-presidency, may also persist (Dagnino, 2002).

The marked presence of Tradition values in Brazilians from the South and Southeast of the country had previously been reported in a meta-analysis conducted by Torres et al. (2015). As such, Tradition occupying the second position in the hierarchy shows a possible cultural influence, when the process of socialization in the Southeast is considered. This may be contributing to the preservation of customs, ideas and traditional practices, hindering the consolidation of changes.

In this respect, the importance attributed to Security $(M=4.56)$ may help understand the value given to Tradition, also ranked second in the hierarchy, with the goal of achieving harmony, social and personal stability, and reciprocal favor exchange (Schwartz, 2005). Council representatives who prioritize this motivational type and value stable relationships and the exchange of favors may result in client practices, compromising negotiations of MSAC policies in an attempt at conserving relations. The consensus between motivational types Tradition and Security is notorious due to their 
position in the value structure and, taken together, denote the search for preserving existing social arrangements that ensure security. In addition to their compatibility, the fact of having similar means reinforces their equal importance for Council representatives.

Conformity $(M=4.11)$, Hedonism $(M=4.07)$ and Achievement $(\mathrm{M}=3.87)$ placed third in the hierarchy of personal values of Council representatives, and were therefore not key values for the study participants. It is important to underscore that the means for Conformity, along with those of Tradition and Security, make Conservation $(M=4.41 ; S D=0.73)$, the second most valued among study participants, demonstrating that, along with promoting others and transcending personal interests, there is a tendency to preserve traditional practices, avoiding changes and novelties and seeking stability and security. Although the Self-direction values are important to Council representatives, the combination of Tradition, Security and later Conformity ultimately held considerable weight in their choices. In this respect, Torres et al. (2015) observed that at least one of the Conservation values was relevant in all regions of Brazil, particularly in the Northeast, Southeast and South.

After analyzing the hierarchy of values obtained for study participants, we sought to describe their value profiles, applying cluster analyses to the ten motivational types of values, a process that identified five clusters (Table 2).

\section{(Table 2) \\ PROFILES OF MOTIVATIONAL TYPES OF VALUES OF MSAC REPRESENTATIVES}

\begin{tabular}{|c|c|c|c|c|c|c|}
\hline \multirow[b]{2}{*}{ Profiles } & \multirow[b]{2}{*}{$\mathrm{N}$} & \multicolumn{2}{|c|}{ Situation at MSAC } & \multicolumn{2}{|c|}{ Sector Represented } & \multirow{2}{*}{$\begin{array}{c}\text { Time } \\
\text { at } \\
\text { MSAC }\end{array}$} \\
\hline & & Full & Substitute & $\begin{array}{c}\text { Public } \\
\text { Authority }\end{array}$ & $\begin{array}{c}\text { Civil } \\
\text { Society }\end{array}$ & \\
\hline $\begin{array}{l}\text { Conservative Self- } \\
\text { transcendence } \\
\text { Combines the axiological } \\
\text { priorities of Self-transcendence } \\
\text { and Conservation (means above } \\
\text { 5.00, except for Tradition), } \\
\text { standing out from the others by } \\
\text { greater comparative preference } \\
\text { for Conformity and Security. }\end{array}$ & 43 & $\begin{array}{c}32 \\
(74.4 \%)\end{array}$ & $\begin{array}{c}11 \\
(25.6 \%)\end{array}$ & $\begin{array}{c}23 \\
(53.5 \%)\end{array}$ & $\begin{array}{c}20 \\
(46.5 \%)\end{array}$ & 28.51 \\
\hline
\end{tabular}

(continue) 


\section{(Table 2 (conclusion)) \\ PROFILES OF MOTIVATIONAL TYPES OF VALUES OF MSAC REPRESENTATIVES}

\begin{tabular}{|c|c|c|c|c|c|c|}
\hline \multirow[b]{2}{*}{ Profiles } & \multirow[b]{2}{*}{$\mathrm{N}$} & \multicolumn{2}{|c|}{ Situation at MSAC } & \multicolumn{2}{|c|}{ Sector Represented } & \multirow{2}{*}{$\begin{array}{l}\text { Time } \\
\text { at } \\
\text { MSAC }\end{array}$} \\
\hline & & Full & Substitute & $\begin{array}{l}\text { Public } \\
\text { Authority }\end{array}$ & $\begin{array}{c}\text { Civil } \\
\text { Society }\end{array}$ & \\
\hline $\begin{array}{l}\text { Moderate Self-transcendence } \\
\text { More importance given to } \\
\text { Benevolence and Universalism, } \\
\text { followed by an emphasis on } \\
\text { Self-direction and a certain value } \\
\text { attributed to Tradition. Rejection } \\
\text { of Self-promotion values, which } \\
\text { obtained very low means. }\end{array}$ & 45 & $\begin{array}{c}35 \\
(77.8 \%)\end{array}$ & $\begin{array}{c}10 \\
(22.2 \%)\end{array}$ & $\begin{array}{c}28 \\
(62.2 \%)\end{array}$ & $\begin{array}{c}17 \\
(37.8 \%)\end{array}$ & 39.52 \\
\hline $\begin{array}{l}\text { Ambiguous Self-transcendence } \\
\text { Nearly all the means are high } \\
\text { (between } 4.3 \text { and 5.6). Relations } \\
\text { of conflict between the types } \\
\text { of values are unclear, signaling a } \\
\text { certain ambiguity. Slight priority } \\
\text { for Self-transcendence values. }\end{array}$ & 55 & $\begin{array}{c}44 \\
(80.0 \%)\end{array}$ & $\begin{array}{c}10 \\
(18.2 \%)\end{array}$ & $\begin{array}{c}34 \\
(61.8 \%)\end{array}$ & $\begin{array}{c}21 \\
(38.2 \%)\end{array}$ & 25.07 \\
\hline $\begin{array}{l}\text { Significant Self-transcendence } \\
\text { Importance given to Self- } \\
\text { transcendence values over } \\
\text { their Self-promotion and Open } \\
\text { to Change counterparts, which } \\
\text { exhibited much lower means } \\
\text { (2.02 to } 3.67) \text { compared to all } \\
\text { other profiles. }\end{array}$ & 29 & $\begin{array}{c}22 \\
(75.9 \%)\end{array}$ & $\begin{array}{c}6 \\
(20.7 \%)\end{array}$ & $\begin{array}{c}11 \\
(37.9 \%)\end{array}$ & $\begin{array}{c}18 \\
(62.1 \%)\end{array}$ & 42.96 \\
\hline $\begin{array}{l}\text { Indifferent } \\
\text { All the means are very similar } \\
\text { (between } 3.62 \text { and } 4.28 \text { ) and } \\
\text { located in the neutral region } \\
\text { of the scale, in a zone of } \\
\text { indifference in relation to the } \\
\text { different motivational types of } \\
\text { values. }\end{array}$ & 32 & $\begin{array}{c}9 \\
(28.1 \%)\end{array}$ & $\begin{array}{c}15 \\
(46.9 \%)\end{array}$ & $\begin{array}{c}11 \\
(35.5 \%)\end{array}$ & $\begin{array}{c}20 \\
(64.5 \%)\end{array}$ & 18.22 \\
\hline Total & 204 & $\begin{array}{c}142 \\
(69.6 \%)\end{array}$ & $\begin{array}{c}52 \\
(25.5 \%)\end{array}$ & $\begin{array}{c}107 \\
(52.7 \%)\end{array}$ & $\begin{array}{c}96 \\
(47.3 \%)\end{array}$ & 30.30 \\
\hline
\end{tabular}

Source: Elaborated by the authors. 
These clusters contribute to identify the value profiles of Council representatives, and the first cluster was denominated Conservative Self-transcendence. With high scores in Benevolence (5.69), Universalism (5.54), Security (5.30) and Conformity (5.19), the main characteristic of the group in question is the combination of Self-transcendence and Conservation values, attributing a certain priority to the former. Although the vast majority of profiles attribute considerable importance to Self-transcendence, the aforementioned group stands out from the others by its tendency to Conservation, primarily in relation to Conformity values, whose mean was notably higher to that observed in other groups. Only Tradition obtained a mean of less than five $(M=4.52)$, remaining, however, between neutrality and agreement.

With respect to the other motivational types, mainly those that involve Self-promotion and Openness to Change values, the means are located largely at the limit between disagreement and neutrality (near 3.00 and 4.00). This profile also exhibited a more balanced composition between representatives of public authorities $(53.5 \%)$ and civil society $(46.5 \%)$, the majority of whom were full members $(74.4 \%)$, with a little more than two years at MSAC, who tended to be concerned for the well-being of the population, as well as to preserve traditional practices.

The second cluster includes Council representatives with a Moderate Self-transcendence profile. With the second longest time served at the MSAC (approximately 40 months), a majority of public authorities representatives (62.2\%), and full members $(77.8 \%)$, the subjects who make up this profile attributed higher means to Benevolence $(M=5.59)$, Universalism $(M=5.55)$, Self-direction $(M=5.18)$ and Tradition $(M=4.77)$. Although greater importance was given to the first two, indicating value in the well-being of others and the promotion of collective interests, the emphasis on Self-direction values shows a certain independence and confidence in their own viewpoints, which tend to prevail over acceptance of the ideas and customs of the group (Tradition), thus creating a moderate Self-transcendence profile. Power and Achievement were the motivational types with the lowest means (2.18 and 3.12 , respectively), indicating rejection of Self-promotion values.

The third profile, designated Ambiguous Self-transcendence, had the largest number of subjects $(n=55)$, composed largely of full members $(80 \%)$ and public authorities representatives $(60 \%)$, where a tendency to response agreement was observed, since nearly all the means are high (between 4.3 and 5.6). Compared to the other profiles, they attributed more relevance to Self-promotion and Openness to Change, primarily in relation to Self-direction $(M=5.39)$, Hedonism $(M=5.05)$ and Achievement $(M=5.03)$. Howe- 
ver, within the group, the values of Universalism $(M=5.56)$ and Benevolence $(M=5.65)$ were also highly valued, as well as Security $(M=4.95)$. As such, the opposition relations between motivational types are not very clear, despite a slight priority for Self-transcendence, very close to ambiguity.

A Significant Self-transcendence profile was identified in cluster number four, composed largely of civil society representatives $(62 \%)$ and full members $(75.9 \%)$ and characterized by the considerable importance attributed to Self-transcendence values, primarily in relation to Self-promotion and Openness to Change, which obtained much smaller means (2.02 to 3.67) compared to all the other profiles. This group also valued Tradition $(M=4.83)$, one of the types of values that shares motivation with Self-transcendence. Thus, there is a clear conflict and compatibility relation among motivational types of values and a pronounced relevance attributed to Benevolence $(M=5.47)$ and Universalism $(M=5.41)$ within this group. It is important to underscore that this profile of values most closely resembles that expected for MSAC representatives, despite comprising the smallest number of individuals $(\mathrm{n}=29)$.

Finally, the fifth profile was Indifferent, since the means of all motivational types are very similar (between 3.62 and 4.28) and situated in the neutral region of the scale. It differs from the other clusters primarily in exhibiting lower means in Universalism $(M=4.11)$ and Benevolence $(M=4.03)$, motivational types with high scores in all the other profiles (more than 5.5) and comparatively elevated means in Power $(M=3.62)$ and Stimulation $(M=4.05)$. In this respect, it represents an atypical profile since it attributes little importance to Self-transcendence and does not overly devalue Self-promotion and Openness to Change, located in a zone of indifference in relation to the different motivational types of values. Given that it is composed largely of substitute members (46.9\%) and a significant number of subjects who are unaware of their situation in the council $(25 \%)$, the group is characterized by low involvement with the routine of the council, which may indicate less affinity with, and even lack of knowledge, regarding the proposal.

Cluster analysis showed that the profiles of Conservative, Moderate and Significant Self-transcendence included the groups whose main tendencies were identified in the analysis of the general axiological priorities of the representatives. As such, the profile of Conservative Self-transcendence represents the group that defends stated practices, and considers the values of Tradition and Security as second in the order of importance attributed to motivational types. Moderate Self-transcendence characterizes respondents whose profile is to value their own ideas to the detriment of the collective, 
symbolized by the marked presence of Self-direction values, which also ranks second in the general hierarchy of values. The group defined by a profile of Significant self-transcendence, in turn, clearly indicates the importance of Benevolence and Universalism compared to the others. However, with respect to the earlier discussions regarding the supposed greater weight given to Benevolence in guiding the actions of MSAC representatives in Minas Gerais, this profile may be present in a group of respondents more concerned with meeting the demands of the sector and/or institution that they represent in the Councils.

Taken together, these results suggest the need to increase the understanding of council representatives' perception about the values of Universalism, in order to guide educational practices aimed at promoting equality, social justice and public policies that meet the collective interests, thereby preserving the acceptance of differences and seeking to create a critical profile in order to consolidate social control. Counselors represent the correlation of forces and diversity present in a given neighborhood or community and are responsible for putting forward their positions and demands, thereby contributing to the ongoing transformation in the field of Social Assistance in Brazil.

\section{FINAL CONSIDERATIONS}

MSACs are entities that struggle for rights and show potential in terms of social participation and democratic social control. They are (or should be) characterized by dialogue and decisions regarding public Social Assistance policies that are deliberated, monitored and assessed by public sector and civil society representatives, in addition to being communication channels for social demands. In this respect, Council representatives play a catalyzing role in the functioning of these potentialities, and the aim of the present study was to analyze the motivational types of human values prioritized by representatives of Municipal Social Assistance Councils, in the municipalities of Minas Gerais, with a view to describe the axiological profiles of the study participants.

The analyses conducted made it possible to achieve the proposed objective, indicating that the most significant types of values were Benevolence and Universalism, followed by Self-direction, Tradition and Security, which shows the importance of Self-transcendence and the tendency to Conservation. Moreover, the results allow us to infer that the importance given to Self-direction values was related more to the affirmation of the participants' 
own ideas in detriment to the collective position, than to the expression of creativity and the introduction of innovations.

Cluster analyses contributed to identify the existence of five profiles of human values in Council representatives. In four of these, Self-transcendence was a central characteristic that assumed different outlines based on the priorities attributed to the other motivational types, ranging from conservative, moderate and ambiguous to a more significant manifestation. Only one profile showed indifference in relation to the different motivational types under study.

As such, the hierarchy of motivational types that guides MSAC representatives partially favors behaviors that may contribute to exploit the existing potentials of these councils. However, one aspect that should be elucidated in future studies is the empirical structure of values displayed by MSAC representatives, which would make it possible to establish how Self-transcendence values arrange in these organizations. If the tendency in Brazilians, identified by Teixeira et al. (2014), that Universalism is located inside and Benevolence outside the circular structure is confirmed, it would indicate an abstract content for Universalism values, and make it possible to infer with greater certainty that the counselors favor behavior that defends the interests of the sector and/or institutions they represent rather than the broader collective interests, preserving the ideals of equality and social justice only on the discursive plane and hindering the realization of the democratic potential of the councils.

The other findings of this study, together with those of other authors who analyzed the dynamics of MSACs (Oliveira, 2009; Falchetti, 2011; Kronemberger et al., 2012; Alves et al., 2013; among others), seem to point in that direction, given that respondents were also conservative, which could compromise the struggle for collective rights, social justice and equality in participation and deliberations, favoring continuation of status quo. On the other hand, the fact that MSAC representatives reject excessive authority and power is a positive aspect for the functioning of Councils.

Thus, despite the contributions of this study, with respect to determine the guiding values of MSAC representatives in Minas Gerais, this investigation presents some limitations. Its quantitative nature means conclusions can only be generalized for MSAC representatives in Minas Gerais, precluding extrapolating to representatives of Municipal Social Assistance Councils throughout Brazil. Furthermore, it does not result in in-depth knowledge of how values are expressed in the activities of these Councils.

As future investigations, we suggest a research involving Council representatives from other states of Brazil, analysis of the empirical structure of counselor values and a possible survey of qualitative data that make it pos- 
sible to confirm or refute the inferences and potential exhibited in this study, discussing the implications of motivational types prioritized in a more direct manner to the reality of MSACs.

In this regard, the practical implications for the Councils of this study lie in identifying predispositions and encouraging Council representatives to promote greater deliberative participation and social control, in addition to uniting public, private and civil society actors. Understanding how they prioritize their values is essential to offer educational and socializing arenas that produce new knowledge and stimulate new forms of commitment, representation and participation in Councils.

\section{VALORES HUMANOS E ASSISTÊNCIA SOCIAL: UM ESTUDO COM REPRESENTANTES EM CONSELHOS MUNICIPAIS}

\section{RESUMO}

Objetivo: Analisar os tipos motivacionais de valores humanos priorizados pelos representantes de Conselhos Municipais de Assistência Social nos municípios do estado de Minas Gerais, buscando delimitar perfis axiológicos entre os participantes do estudo.

Originalidade/lacuna/relevância/implicações: O estudo fundamenta-se na teoria dos valores humanos de Schwartz (1992), aplicando suas contribuições para auxiliar na compreensão de uma realidade ainda não explorada nas pesquisas de valores, qual seja a dos Conselhos de Assistência Social no Brasil, não obstante as transformações recentes que vêm experimentando num esforço de mudança de sua própria concepção enquanto política pública.

Principais aspectos metodológicos: Os dados foram coletados por meio de aplicação do questionário PQ-21 a uma amostra de 204 respondentes. Foram utilizadas análises descritivas, teste Anova e análises de cluster.

Síntese dos principais resultados: Os tipos motivacionais mais enfatizados pelos respondentes foram Benevolência e Universalismo, seguidos por Autodeterminação, Tradição e Segurança, o que revela valorização dos interesses do grupo social e da comunidade, acompanhada de necessidade de afirmação das próprias ideias e preservação de práticas tradicionais e seguras. Cinco perfis axiológicos foram identificados a partir 
das análises de cluster, observando-se, em quatro deles, a Autotranscendência como característica central.

Principais considerações/conclusões: A relevância atribuída aos valores de Autotranscendência e Conservação, nessa ordem, sinaliza certa preocupação com o bem-estar social e a participação política, com tendência, entretanto, à aceitação e à manutenção de práticas tradicionais, que podem dificultar os processos de transformação no contexto estudado. Estudos futuros podem esclarecer tais relações, beneficiando-se da utilização complementar de levantamento qualitativo.

\section{PALAVRAS-CHAVES}

Valores humanos. Assistência social. Conselhos municipais. Representantes em conselhos municipais. Participação social.

\section{VALORES HUMANOS Y ASISTENCIA SOCIAL: UN ESTUDIO CON LOS REPRESENTANTES EN LOS CONSEJOS MUNICIPALES}

\section{RESUMEN}

Objetivo: Analizar los tipos motivacionales de valores humanos priorizados por los representantes de los Consejos Municipales de Asistencia Social en los municipios de Minas Gerais, Brasil, tratando de delimitar el perfil axiológico entre los participantes en el estudio.

Originalidad/laguna/relevancia/implicaciones: El estudio se basa en la teoría de los valores humanos de Schwartz (1992), aplicando sus contribuciones para comprender una realidad inexplorada en la investigación de valores, a saber, los Consejos de Asistencia Social en Brasil, a pesar de las recientes transformaciones destinadas a cambiar su concepción como política pública.

Principales aspectos metodológicos: Los datos se recopilaron aplicando el cuestionario PQ-21 a una muestra de 204 encuestados. Se utilizaron análisis descriptivo, Anova y análisis de conglomerados.

Síntesis de los principales resultados: Los tipos motivacionales más enfatizados por los encuestados fueran Benevolencia y Universalismo, seguido por Autodeterminación, Tradición y Seguridad, lo que demuestra 
apreciación de los intereses del grupo social y la comunidad, acompañado de la necesidad de una declaración de las ideas propias y preservación de las prácticas tradicionales y seguras. Cinco perfiles axiológicos fueron identificados en el análisis de conglomerados, y en cuatro de ellos, la Autotrascendencia fue una característica central.

Principales consideraciones/conclusiones: La importancia atribuida a la Auto-trascendencia y Conservación, en ese orden, indica cierta preocupación por el bienestar y la participación política, aunque con tendencia a aceptar y mantener las prácticas tradicionales que pueden dificultar procesos de transformación en el contexto estudiado. Los estudios futuros pueden aclarar estas relaciones con el uso complementario de la investigación cualitativa.

\section{PALABRAS CLAVE}

Valores humanos. Asistencia social. Consejos municipales. Representantes en consejos municipales. Participación social.

\section{$\int$ REFERENCES}

Alves, C. C., Damião, V. A. N., \& Mafra, L. A. S. (2013). A correlação de forças entre o estado e a sociedade civil: estudo de caso do conselho de assistência social de um município sul-mineiro. Anais do Simpósio Mineiro de Assistentes Sociais, Belo Horizonte, Minas Gerais, 4.

Brasil. (2011). Leis e Decretos. Lei $\mathrm{n}^{\circ}$. 12.435, de 6 de julho de 2011 . Altera a Lei $n^{\circ}$ 8.742, de 7 de dezembro de 1993, que dispõe sobre a organização da Assistência Social. Brasília, DF.

Brasil. (2013). Ministério do Desenvolvimento Social e Combate à Fome. Relatório Censo SUAS 2013. Brasília, DF: Secretaria de Avaliação e Gestão da Informação; Secretaria Nacional de Assistência Social. Retrieved from http:// aplicacoes.mds.gov.br/sagirmps/ferramentas/docs/CensoSUAS_2013_ completo.pdf

Coelho, J. A. P. de M., Gouveia, V. V., \& Milfont, T. L. (2006). Valores humanos como explicadores de atitudes ambientais e intenção de comportamento pró-ambiental. Psicologia em Estudo, 11 (1), 199-207.

Conselho Nacional de Assistência Social. (2011). Resolução n. 6, de 9 de fevereiro de 2011. Define o Regimento Interno do Conselho Nacional de Assistência Social. Brasília, DF, 2011. 
Dagnino, E. (2002). Participação política em conselhos gestores de políticas sociais no Paraná. In R. Perissinotto \& M. Fuks. Democracia: teoria e prática. Rio de Janeiro: Relume Dumará; Curitiba: Fundação Araucária.

Falchetti, C. (2011). Novos arranjos e velhos dilemas na democratização das politticas sociais: os conselhos de políticas públicas e a experiência de Araraquara. São Paulo: Cultura Acadêmica.

González-Rodrigues, M. R., Díaz-Fernández, M. C., Spers, V. R., \& Leite, M. S. (2016). Relation between background variables, values and corporate social responsibility. Revista de Administração de Empresas, 56(1), 8-19.

Instituto Brasileiro de Geografia e Estatística, (2010). Perfil dos municípios brasileiros: assistência social 2009. Rio de Janeiro. Retrieved from http://www. ibge.gov.br/home/presidencia/noticias/noticia_visualiza.php?id_noticia $=1620 \& i d \_p a g i n a=1$.

Jesuíno, J. C., Torres, C. V., \& Teixeira, M. L. M. (2012). Avanços teóricos e metodológicos em valores humanos e gestão: uma introdução ao fórum. Revista de Administração Mackenzie, 13(3), 14-17.

Kronemberger, T. S., Tenório, F. G., Dias, A. F., \& Barros, A. C. R. (2012). Os conselhos municipais de políticas públicas sob o olhar da comunidade: uma experiência de extensão universitária. Anais do Encontro Nacional de Pesquisadores em Gestão Social, São Paulo, SP, Brasil, 4.

Leite, U. R., Tamayo, A., \& Günther, H. (2003). Organização do uso do tempo e valores de universitários. Avaliação Psicológica, 2(1), 57-66.

Ministério do Desenvolvimento Social e Combate à Fome. (2012). Relatório Censo SUAS 2012. Brasília, DF: Secretaria de Avaliação e Gestão da Informação; Secretaria Nacional de Assistência Social, 2013. Retrieved from http:// aplicacoes.mds.gov.br/sagi/simulacao/status_censo_2012/relatorio_status_censo_uf.php

Oliveira, V. C. S. (2009). Sociedade, estado e administração pública: análise da configuração institucional dos conselhos gestores do município de Lavras, MG. Tese de doutorado, Universidade Federal de Lavras (Ufla), Lavras, MG.

Porto, J. B., \& Tamayo, A. (2002). Prioridades axiológicas e regiões brasileiras: preditores de civismo nas organizações. Revista Psicologia: Organizações e Trabalho, 2(1), 31-61.

Porto, R. B., \& Torres, C. V. (2014). Valores humanos como moderadores e supressores na preferência do consumidor por marcas e produtos. Estudos de Psicologia, 19(2), 91-101.

Raichelis, R. (2007). Esfera pública e conselhos de assistência social: caminhos da construção democrática. São Paulo: Cortez. 
Ros, M. (2006). Psicologia social dos valores: uma perspectiva histórica. In M. Ros \& V. Gouveia. (Eds.). Psicologia social dos valores humanos: desenvolvimentos teóricos, metodológicos e aplicados. (pp. 23-54). São Paulo: Senac.

Sambiase, M. F., Teixeira, M. L. M., Bilsky, W., Araujo, B. F. V. B., \& Domenico, S. M. R. (2014). Confrontando estruturas de valores: um estudo comparativo entre PVQ-40 e PVQ-21. Psicologia: Reflexão e Crítica, 27(4), 728-739.

Schwartz, S. H. (1992). Universals in the content and structure of values: theoretical advances and empirical tests in 20 countries. In M. Zanna (Ed.). Advances in experimental social Psychology (vol. 25, pp. 1-65). New York: Academic Press.

Schwartz, S. H. (1994). Are there universal aspects in the structure and contents of human values?. Journal of Social Issues, 50(4), 19-45.

Schwartz, S. H. (2005). Valores humanos básicos: seu contexto e estrutura intercultural. In A. Tamayo \& J. B. Porto (Eds.). Valores e comportamento nas organizações (pp. 21-55). Petrópolis: Vozes.

Schwartz, S. H. (2011). Studying values: personal adventure, future directions. Journal of Cross-Cultural Psychology, 42 (2), 307-319.

Schwartz, H. S., Cieciuch, J., Vecchione, M., Davidov, E., Fisher, R., Beierlein, C., Ramos, A., Verkasalo, M., Lonnqvist, J. E., Demirutku, K., Dirilen-Gumus, O., \& Konty, M. (2012). Refining the theory of basic individual values. Journal of Personality and Social Psychology, 103(4), 663-688.

Schwartz, S. H., \& Bilsky, W. (1987). Toward a universal psychological structure of human values. Journal of Personality and Social Psychology, 53(3), 550-562.

Sobral, F. J. B. A., \& Gimba, R. F. G. (2012). As prioridades axiológicas do líder autêntico: um estudo sobre valores e liderança. Revista de Administração Mackenzie, 13(3), 96-121.

Tamayo, A., \& Schwartz, S. H. (1993). Estrutura motivacional dos valores humanos. Psicologia: Teoria e Pesquisa, 9(2), 329-348.

Tamayo, A., \& Porto, J. B. (2009). Validação do Questionário de Perfis de Valores (QPV) no Brasil. Psicologia: Teoria e Pesquisa, 25(3), 369-376.

Teixeira, M. L. M., Sambiase, M. F., Janik, M., \& Bilsky, W. (2014). Peculiaridades da estrutura de valores básicos dos brasileiros. Revista Psicologia: Organizações e Trabalho, 14(2), 139-152.

Torres, C. V., Porto, J. B., Vargas, L. M., \& Fischer, R. (2015). A meta-analysis of basic human values in Brazil: observed differences within the country. Revista Psicologia: Organizações e Trabalho, 15(1), 89-102. 